Hal. $311-322$

\title{
PENENTUAN STRATEGI PENINGKATAN RETRIBUSI PELAYANAN PERSAMPAHAN/KEBERSIHAN PERMUKIMAN DI KABUPATEN SITUBONDO
}

\author{
Chusla Indah Ayu Wulandari \\ Dinas Pekerjaan Umum Cipta Karya dan Tata Ruang Kabupaten Situbondo \\ chusla_indah4yu@yahoo.com
}

\begin{abstract}
The regional readiness to implement regional autonomy is measured from its financial capability that mainly sourced from the Regional Own-Source Revenue (PAD). The problem is that regional retributions as one of the PAD's components have not been able to contribute significantly to the overall regional revenue. One of the causes is the lack of potential sources exploration. This also happened to the retribution of the waste management services of the settlement in Situbondo Regency. This study aims to identify opportunities, threats, strengths, weaknesses, and strategies that can be applied to increase the waste management services of the settlement in Situbondo Regency. The strategy is formulated by using Internal External (IE) and Strengths, Weaknesses, Opportunities, and Threats (SWOT) matrixes. Findings of the research show that opportunities and threats are consisted of the potential retributions payer, increasing numbers of housing, public awareness, parliament control, retribution rates, sanctions for the retribution payer, and competitors. The strengths and weaknesses are consisted of coordination between legislative party and relevant insitutions, the quantity and quality of the retribution collector, waste services, leakage control, quantity of the waste hauler, facilities and infrastructure, socialization, SOP, retribution tariff, and retribution contribution to the PAD. The main strategy to increase the revenue from the waste management service is the expansion strategy in the form of extensification by extending the coverage area of the retribution.
\end{abstract}

Keywords: Strategy, Waste Services Retribution, Settlements.

\begin{abstract}
Abstrak:Kesiapan daerah dalam melaksanakan otonomi daerah diukur dari kemampuan keuangan suatu daerah yang sumber keuangan utamanya berasal dari Pendapatan Asli Daerah (PAD). Permasalahannya adalah bahwa retribusi daerah sebagai salah satu komponen PAD belum bisa memberikan kontribusi yang signifikan terhadap penerimaan daerah secara keseluruhan. Salah satu penyebabnya adalah penggalian potensi yang kurang menyeluruh. Hal ini juga terjadi pada retribusi pelayanan persampahan/kebersihan permukiman di Kabupaten Situbondo. Penelitian ini bertujuan untuk mengidentifikasi peluang, ancaman, kekuatan, dan kelemahan sertauntuk mengidentifikasi strategi yang dapat diterapkan dalam peningkatan retribusi pelayanan persampahan/kebersihan pada permukiman di Kabupaten Situbondo. Perumusan alternatif strategi yang ada menggunakan matriks IE dan matriks SWOT. Hasil penelitian menunjukkan bahwa peluang dan ancaman terdiri dari potensi wajib retribusi, pertambahan perumahan/permukiman, kesadaran masyarakat, pengawasan DPRD, tarif retribusi, sanksi wajib retribusi, dan pesaing. Sedangkan kekuatan dan kelemahannya terdiri dari koordinasi dengan pihak legislatif dan instansi terkait, kuantitas dan kualitas pemungut retribusi, pelayanan persampahan, pengawasan kebocoran, kuantitas pengangkut sampah,
\end{abstract}


sarana dan prasarana, sosialisasi, SOP, pemungutan tarif retribusi, dan kontribusi retribusi terhadap PAD. Strategi utama yang dapat diterapkan dalam peningkatan retribusi pelayanan persampahan/kebersihan adalah strategi ekspansi dalam bentuk ekstensifikasi yaitu dengan melakukan perluasan cakupan layanan retribusi pelayanan persampahan/kebersihan.

Kata Kunci:Strategi, Retribusi Persampahan, Pemukiman.

\section{Pendahuluan}

Otonomi daerah yang merupakan suatu kebijakan pemerintah sebagai solusi perbaikan pelayanan publik dan peningkatan kesejahteraan masyarakat, dimana masingmasing daerah diberikan hak, kewajiban dan kewenangan yang luas untuk mengatur dan mengurus rumah tangganya sendiri. Tolak ukur yang digunakan untuk melihat kesiapan daerah dalam melaksanakan otonomi daerah tersebut adalah dengan mengukur seberapa besar kemampuan keuangan suatu daerah dalam kaitannya dengan pelaksanaan otonomi daerah. Sumber keuangan utama yang digunakan untuk menunjang kemampuan keuangan daerah untuk melaksanakan pengaturan rumah tangganya sendiri adalah berasal dari Pendapatan Asli Daerah (PAD). Retribusi daerah sebagai salah satu sumber PAD merupakan salah satu sumber yang cukup potensial. Djalil (2014:306) menyatakan bahwa seluruh sumber PAD tersebut, pajak dan retribusi daerah mendominasi hampir secara keseluruhan, sementara bagian terkecil biasanya berasal dari lain-lain PAD yang sah. Selain itu retribusi daerah juga merupakan sumber penerimaan yang dapat dipungut terus menerus mengingat pengeluaran pemerintah daerah adalah untuk anggaran rutin dan anggaran pembangunan yang selalu meningkat. Namun pada kenyataannya, masih terdapat berbagai permasalahan retribusi daerah, diantaranya adalah retribusi tersebut belum memberikan kontribusi yang signifikan terhadap penerimaan daerah secara keseluruhan

Permasalahan akan minimnya penerimaan retribusi daerah sebagai salah satu sumber dari PAD juga dialami oleh Kabupaten Situbondo. Salah satunya terjadi pada retribusi pelayanan persampahan/kebersihan. Permasalahan yang ada yaitu jumlah realisasi retribusi pelayanan persampahan/kebersihan di Kabupaten Situbondo lebih kecil dari target yang telah ditetapkan. Hal tersebut dapat dilihat pada Tabel 1 di bawah ini. 
Tabel 1: Pagu Anggaran Dan Realisasi Retribusi Pelayanan Persampahan / Kebersihan Tahun 2010-2014

\begin{tabular}{|c|c|c|c|c|c|}
\hline \multirow{3}{*}{ Uraian } & \multicolumn{5}{|l|}{ Tahun } \\
\hline & 2010 & 2011 & 2012 & 2013 & 2014 \\
\hline & Anggaran & Anggaran & Anggaran & Anggaran & Anggaran \\
\hline \multirow{3}{*}{$\begin{array}{l}\text { Retribusi } \\
\text { pelayanan } \\
\text { persampahan } \\
\text { /kebersihan }\end{array}$} & 196.093 .400 & 208.717 .000 & 227.647 .000 & 489.507 .950 & 330.364 .750 \\
\hline & Realisasi & Realisasi & Realisasi & Realisasi & Realisasi \\
\hline & 202.653 .900 & 216.222.200 & 263.903 .550 & 304.401 .600 & 347.053 .750 \\
\hline
\end{tabular}

Sumber: Laporan Realisasi Anggaran Kabupaten Situbondo, 2014

Pada tahun 2013 dapat diketahui bahwa penerimaan atas retribusi pelayanan persampahan/ kebersihan tidak dapat memenuhi target yang telah ditetapkan, sehingga menyebabkan adanya penurunan target untuk tahun berikutnya salah satunya dikarenakan penggalian potensi terkait potensi atas wajib retribusi pelayanan persampahan/kebersihan yang belum menyeluruh, dimana masih terdapat potensi-potensi atas sumber-sumber pendapatan atas retribusi pelayanan persampahan/kebersihan yang masih dapat digali lagi salah satunya dari permukiman terutama dari sektor perumahan. Di Situbondo, rumahrumah yang berada di area perumahan yang merupakan bagian dari permukiman belum dijadikan sebagai objek retribusi, karena selama ini hanya rumah-rumah yang berada di pinggir jalan saja yang dijadikan sebagai wajib retribusi. Padahal jumlah perumahan di Situbondo tiap tahun selalu mengalami peningkatan/penambahan. Selain itu, Peraturan Daerah Kabupaten Situbondo Nomor 5 Tahun 2011 tentang retribusi pelayanan persampahan/kebersihan, juga menyebutkan bahwa rumah kediaman sudah termasuk dalam lokasi pemungutan sebagai objek dari retribusi pelayanan persampahan/kebersihan.

Kondisi di atas menunjukkan bahwa perlu adanya evaluasi ulang terhadap strategi kebijakan mengenai retribusi daerah Kabupaten Situbondo. Upaya yang dapat dilakukan oleh Pemerintah Kabupaten Situbondo dalam rangka meningkatkan penerimaan retribusi daerah adalah melalui manajemen strategi peningkatan PAD yang tepat, dengan melihat dan mempertimbangkan berbagai perubahan lingkungan baik internal maupun eksternal.

Strategi menurut Amirullah (2015:4) merupakan suatu kesatuan rencana perusahaan yang menyeluruh, komprehensif, dan terpadu yang digunakan untuk mencapai tujuan perusahaan. Ada tiga tahapan (three-stage) kerangka kerja yang dilakukan untuk menentukan strategi utama dengan matriks sebagai model analisisnya (David, 2011:324). 
a. tahap Input yaitu dengan menentukan faktor strategi eksternal perusahaan/Matriks Evaluasi Faktor Eksternal (Matriks EFE) dan menentukan faktor strategi internal perusahaan/Matriks Evaluasi Faktor Internal (Matriks IFE)

b. tahap pencocokan dengan menggunakan Matriks SWOT dan Matriks IE (InternalEksternal)

c. tahap pengambilan keputusan dengan menggunakan Matriks Perencanaan Strategis Kuantitatif (Quantitive Strategic Planning Matrix-QSPM).

Secara teoritis, memang sebaiknya semua alternatif strategi yang ada haruslah dipertimbangkan, tetapi hal tersebut tidak mungkin, karena (Sofyan, 2015:94):

a. alternatif strategi yang ada hanya sebagian atau secara sampling saja.

b. jika itu dilaksanakan akan menghabiskan banyak waktu dan biaya.

c. adanya persepsi manajerial terhadap risiko, tegantung pada strategi sebelumnya, dan kekuasaan yang sifatnya terbatas.

Sehingga perlu adanya pemilihan strategi sebagai grand strategy (strategi utama) dari beberapa alternatif strategi yang ada. Alternatif strategi utama yang umum digunakan oleh perusahaan yaitu: strategi ekspansi, strategi stabilitas, strategi penciutan dan strategi kombinasi (Sofyan, 2015:80). Berdasarkan penjelasan di atas, penelitian ini bertujuan untuk mengidentifikasi strategi yang dapat diterapkan untuk meningkatkan retribusi pelayanan persampahan/kebersihan pada permukiman di Kabupaten Situbondo.

\section{Metodologi}

Penelitian ini adalah penelitian deskriptif analitis yang dilakukan di Kabupaten Situbondo. Sasaran dalam penelitian ini adalah instansi pemerintahan, yaitu Dinas Pekerjaan Umum Cipta Karya dan Tata Ruang (DPU CKTR) dan Dinas Pendapatan, Pengelola Keuangan dan Aset Daerah (DPPKAD) Kabupaten Situbondo. Sedangkan penentuan sampel penelitian dilakukan dengan menggunakan teknik purposive sampling dengan kriteria:

a. pihak pejabat yang berkaitan langsung dengan retribusi pelayanan persampahan/kebersihan permukiman,

b. karyawan Dinas PU Cipta Karya dan Tata Ruang yang menangani proses pemungutan retribusi pelayanan persampahan/kebersihan.

Sedangkan responden tambahan adalah mereka yang dapat memberikan informasi tentang objek yang akan diteliti walaupun tidak terlibat langsung dalam proses pemungutan retribusi yaitu karyawan yang termasuk dalam bidang kebersihan dan pertamanan yang merupakan petugas yang terlibat dalam proses pengangkutan sampah maupun tidak, dimana responden tersebut mengetahui informasi tentang objek yang akan diteliti. Teknik 
pengumpulan data dilakukan dengan dengan menggunakan metode wawancara dan kuisioner serta dokumentasi.

Penelitian ini adalah penelitian univariat yang hanya menganalisis satu variabel saja yaitu strategi peningkatan retribusi pelayanan persampahan/kebersihan permukiman di Kabupaten Situbondo, yang merupakan suatu cara atau tindakan yang dilakukan oleh Dinas Pekerjaan Umum Cipta Karya dan Tata Ruang (DPU CKTR) dalam upaya meningkatkan retribusi pelayanan persampahan/kebersihan yang terutama berasal dari sektor permukiman yang ada di Kabupaten Situbondo, yang dianalisis dengan menggunakan analisis SWOT.

a. Analisis kontribusi.

Analisis data menentukan besarnya kontribusi Retribusi Jenis Jasa Umum terhadap PAD (Halim, 2004:163)

$$
\text { Kontribusi }=\frac{\text { Realiasi Jenis Retribusi Jasa Umum }}{\text { Realisasi Pendapatan Asli Daerah }} \times 100 \%
$$

dengan kriteria hasil (menurut Bawasir dalam Rozzaq, 2010 ):

$0 \%-0,9 \%=$ relatif tidak memiliki kontribusi

$1 \%-1,9 \% \quad=$ kurang memiliki kontribusi

$2 \%-2,9 \% \quad=$ cukup memiliki kontribusi

$3 \%-3,9 \%=$ memiliki kontribusi

Lebih dari $4 \%=$ sangat memiliki kontribusi

b. Matriks IFAS (Internal Strategic Factors Analysis Summary) dan EFAS (Eksternal Strategic Factors Analysis Summary).

c. Matriks SWOT.

\section{Hasil dan Pembahasan}

Penyelenggaraan Sistem Pemungutan Retribusi Pelayanan Persampahan/Kebersihan di Kabupaten Situbondo

Penerapan terkait retribusi ini diatur menurut Peraturan Daerah Kabupaten Situbondo Nomor 5 Tahun 2011, dimana instansi yang mempunyai kewenangan dalam memungut retribusi pelayanan persampahan/kebersihan di Kabupaten Situbondo khususnya pada permukiman adalah Dinas Cipta Karya yang pada tahun 2014 yang telah berubah nama menjadi Dinas Pekerjaan Umum Cipta Karya dan Tata Ruang (Dinas PU Cipta Karya dan Tata Ruang). Pelaksanaan dalam melayani kepentingan umum terkait persampahan, baik tentang pengelolaan sampah maupun dalam retribusi pelayanan persampahan/kebersihan ditangani langsung oleh seksi Penanganan Sampah yang dan seksi Kebersihan Kota di bawah bidang Kebersihan dan Pertamanan yang merupakan 
salah satu bidang pada instansi Dinas Pekerjan Umum Cipta Karya dan Tata Ruang Kabupaten Situbondo.

\section{Analisis Data}

a. Analisis Kontribusi Retribusi Pelayanan Persampahan/Kebersihan terhadap Pendapatan Asli Daerah (PAD)

Penerimaan retribusi persampahan yang selalu meningkat dan hampir selalu memenuhi target setiap tahunnya ternyata masih belum bisa memberikan kontribusi yang cukup terhadap PAD bahkan dapat dikatakan masih tidak memberikan kontribusi terhadap PAD. Berikut akan disajikan Tabel 3 tentang kontribusi retribusi pelayanan persampahan/kebersihan terhadap PAD selama tahun 2010-2014.

Tabel 2: Kontribusi Retribusi Pelayanan Persampahan/Kebersihan Terhadap PAD Kabupaten Situbondo

\begin{tabular}{lccccc}
\hline Tahun & $\begin{array}{c}\text { Target Retribusi } \\
\text { Persampahan/K } \\
\text { ebersihan (Rp) }\end{array}$ & $\begin{array}{c}\text { Retribusi } \\
\text { Persampananan/ } \\
\text { Kebersihan } \\
(\text { Rp) }\end{array}$ & Realisasi PAD (Rp) & $\begin{array}{c}\text { Kontri- } \\
\text { busi } \\
(\%)\end{array}$ & $\begin{array}{c}\text { Kriteria } \\
\text { Kontribusi }\end{array}$ \\
\hline 2010 & $196.093 .400,00$ & $202.653 .900,00$ & $46.615 .898 .585,26$ & 0,43 & $\begin{array}{l}\text { Tidak Memiliki } \\
\text { Kontribusi }\end{array}$ \\
\hline 2011 & $208.717 .000,00$ & $216.222 .200,00$ & $61.761 .290 .501,85$ & 0,35 & $\begin{array}{l}\text { Tidak Memiliki } \\
\text { Kontribusi }\end{array}$ \\
\hline 2012 & $227.647 .000,00$ & $263.903 .550,00$ & $67.050 .480 .515,22$ & 0,39 & $\begin{array}{l}\text { Tidak Memiliki } \\
\text { Kontribusi }\end{array}$ \\
\hline 2013 & $489.507 .950,00$ & $304.401 .600,00$ & $78.043 .407 .931,91$ & 0,39 & $\begin{array}{l}\text { Tidak Memiliki } \\
\text { Kontribusi }\end{array}$ \\
\hline 2014 & $330.364 .750,00$ & $347.053 .750,00$ & $129.640 .577 .933,6$ & 0,27 & $\begin{array}{l}\text { Tidak Memiliki } \\
\text { Kontribusi }\end{array}$ \\
\hline Rata-rata & & & & 0,37 & $\begin{array}{l}\text { Tidak Memiliki } \\
\text { Kontribusi }\end{array}$ \\
\hline
\end{tabular}

Sumber: Laporan Realisasi Anggaran (diolah) DPPKAD, 2014

b. Matriks EFAS (Eksternal Strategic Factors Analysis Summary) dan IFAS (Internal Strategic Factors Analysis Summary)

Untuk merumuskan matriks EFAS dan IFAS dan juga matriks SWOT, sebelumnya diperlukan adanya analisis terhadap lingkungan eksternal dan internal untuk memberikan gambaran tentang faktor-faktor yang menjadi kekuatan (strengh), kelemahan (weakness), peluang (opportunity) dan ancaman (treaths). Analisis dilakukan melalui wawancara terstruktur. Berdasarkan analisis yang telah dilakukan, dapat dirumuskan matriks EFAS dan matriks IFAS sebagai berikut: 
Tabel 3: Eksternal Factors Analysis Summary (EFAS) Peningkatan Retribusi Pelayanan Persampahan/Kebersihan Dinas PU Cipta Karya dan Tata Ruang

\begin{tabular}{lllll}
\hline \multicolumn{1}{l}{ No. } & \multicolumn{1}{c}{ Indikator Variabel Eksternal } & Bobot & Rating & Score \\
\hline \multicolumn{2}{l}{ PELUANG } & & & \\
\hline 1 & Potensi wajib retribusi & 0,198 & 3 & 0,594 \\
\hline 2 & Pertambahan perumahan/permukiman & 0,159 & 3 & 0,477 \\
\hline $3 \quad \begin{array}{l}\text { Kesadaran masyarakat dalam } \\
\text { membayar retribusi }\end{array}$ & 0,148 & 4 & 0,592 \\
\hline 4 & Pengawasan oleh DPRD & 0,126 & 3 & 0,378 \\
\hline ANCAMAN & & & 0,548 \\
\hline 1 & $\begin{array}{l}\text { Tarif retribusi yang belum proporsional } \\
\text { dengan kondisi lingkungan }\end{array}$ & 0,137 & 0,33 \\
\hline $\begin{array}{l}\text { Pengenaan sanksi bagi wajib retribusi } \\
\text { yang tidak melaksanakan kewajibannya }\end{array}$ & 0,11 & 3 & 0,242 \\
\hline $\begin{array}{l}\text { Adanya pesaing (sebagai pemungut } \\
\text { retribusi dari pihak luar) }\end{array}$ & 0,121 & 2 & 3,161 \\
\hline
\end{tabular}

Sumber: Data Primer (diolah)

Tabel 4: Internal Factors Analysis Summary (IFAS) Peningkatan Retribusi Pelayanan Persampahan/Kebersihan Dinas PU Cipta Karya dan Tata Ruang

\begin{tabular}{|c|c|c|c|c|}
\hline No. & Indikator Variabel Internal & Bobot & Rating & Score \\
\hline \multicolumn{5}{|c|}{ KEKUATAN } \\
\hline 1 & $\begin{array}{l}\text { Koordinasi dengan pihak legislatif } \\
\text { maupun intern pemerintahan }\end{array}$ & 0,1 & 3 & 0,3 \\
\hline 2 & $\begin{array}{l}\text { Memiliki SDM sebagai pemungut } \\
\text { retribusi } \\
\text { persampahan/kebersihan yang cukup }\end{array}$ & 0,1 & 3 & 0,3 \\
\hline 3 & $\begin{array}{l}\text { Kualitas SDM penarik atau pemungut } \\
\text { retribusi } \\
\text { persampahan/kebersihan }\end{array}$ & 0,093 & 3 & 0,279 \\
\hline 4 & Pelayanan persampahan & 0,1 & 4 & 0,4 \\
\hline \multicolumn{5}{|c|}{ KELEMAHAN } \\
\hline 1 & $\begin{array}{l}\text { Pengawasan/kontrol sebagai upaya } \\
\text { pengendalian kebocoran pendapatan }\end{array}$ & 0,083 & 4 & 0,332 \\
\hline 2 & $\begin{array}{l}\text { Kecukupan SDM sebagai pengangkut } \\
\text { sampah }\end{array}$ & 0,107 & 3 & 0,321 \\
\hline 3 & $\begin{array}{l}\text { Sarana dan prasarana fisik persampahan } \\
\text { yang tersedia }\end{array}$ & 0,083 & 3 & 0,249 \\
\hline
\end{tabular}




\begin{tabular}{|c|c|c|c|c|}
\hline 4 & $\begin{array}{l}\text { Sosialisasi terkait retribusi pelayanan } \\
\text { persampahan/kebersihan kepada } \\
\text { masyarakat, terutama masyarakat } \\
\text { penghuni perumahan/permukiman }\end{array}$ & 0,076 & 4 & 0,304 \\
\hline 5 & SOP yang belum sempurna & 0,086 & 3 & 0,258 \\
\hline 6 & $\begin{array}{l}\text { Pemungutan tarif retribusi yang tidak } \\
\text { sesuai Perda }\end{array}$ & 0,09 & 3 & 0,27 \\
\hline \multirow[t]{2}{*}{7} & $\begin{array}{l}\text { Kontribusi retribusi } \text { pelayanan } \\
\text { persampahan/kebersihan terhadap PAD }\end{array}$ & 0,083 & 3 & 0,249 \\
\hline & TOTAL & 100 & & 3,262 \\
\hline
\end{tabular}

Sumber: Data Primer (diolah)

Berdasarkan tabel hasil EFAS dan IFAS di atas, posisi Dinas PU Cipta Karya dan Tata Ruang pada matriks IE dapat digambarkan pada Gambar 1 sebagai berikut:

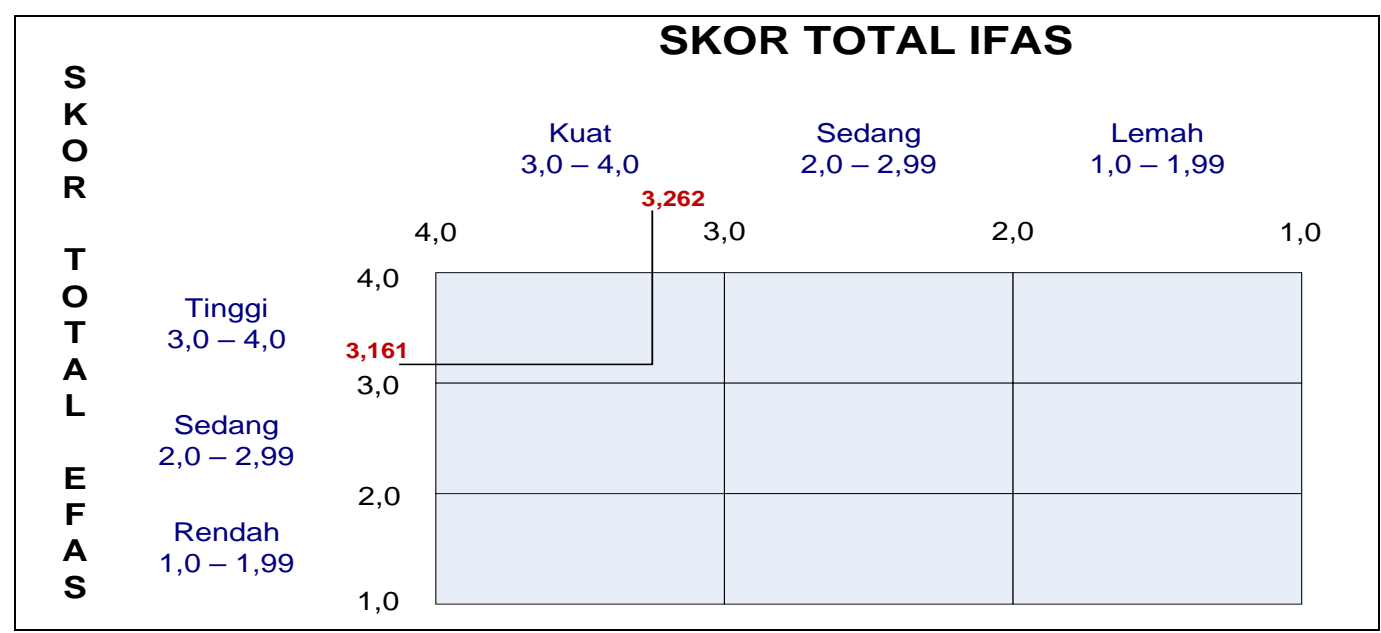

Gambar 1. Matriks strategi IE dinas PU Cipta Karya dan Tata Ruang Kabupaten Situbondo

Sumber: Hasil analisis data, 2015

Hasil pemetaan dalam matriks IE yang ditunjukkan Gambar 1 di atas, menunjukkan bahwa posisi Dinas PU Cipta Karya dan Tata Ruang Kabupaten Situbondo berada pada sel I, yang dapat digambarkan berada pada posisi Grow and Build (tumbuh dan membangun). Strategi-strategi yang cocok dalam posisi tersebut adalah strategi intensif dan strategi integrasi. Strategi intensif dalam peningkatan retribusi pelayanan persampahan/kebersihan di Kabupaten Situbondo dapat dilakukan dengan langkah berikut:

1) penegakan sanksi bagi wajib retribusi yang tidak melaksanakan kewajibannya,

2) meningkatkan pelayanan persampahan,

3) mengoptimalkan sosialisasi dan penyuluhan tentang retribusi pelayanan persampahan/kebersihan termasuk mengenai tarif dan retribusi sampah, 
4) melakukan pengkajian ulang terhadap Perda Retribusi Pelayanan Persampahan/Kebersihan,

5) melakukan revisi atau penyempurnaan terhadap Standar Operasional Prosedur (SOP).

Sedangkan strategi integrasi dalam peningkatan retribusi pelayanan persampahan/kebersihan di Kabupaten Situbondo dapat dicapai melalui integrasi vertikal dan horizontal, dimana integrasi vertikal tersebut dapat dilakukan dengan langkah

1) Pengoptimalan pengawasan DPRD sebagai pihak legislatif terhadap kinerja maupun dalam hal perumusan kebijakan.

2) Merevisi Perda Retribusi Pelayanan Persampahan/Kebersihan yang disesuaikan dengan perkembangan yang ada.

3) Meningkatkan koordinasi dengan seluruh instansi terkait untuk mengatasi pesaing.

Sedangkan strategi integrasi horizontal oleh Dinas PU Cipta Karya dan Tata Ruang tersebut dapat dilakukan dengan melakukan koordinasi dan kerjasama dengan pesaing yang ada untuk meningkatkan kontribusi sampah terhadap PAD.

c. Matriks SWOT

Alternatif strategi peningkatan retribusi pelayanan persampahan/kebersihan permukiman di Kabupaten Situbondo dapat ditentukan oleh kombinasi faktor internal dan faktor eksternal, yaitu dengan menggunakan key success factors yang telah dianalisis dalam matriks sebelumnya. Alternatif strategi yang dihasilkan berdasarkan matriks SWOT adalah sebagai berikut:

1) Strategi SO (Strengh-Opportunity)

a. Meningkatkan atau menambah target retribusi sampah.

b. Memperluas cakupan layanan retribusi pelayanan persampahan/kebersihan, termasuk sektor perumahan/permukiman.

2) Strategi WO (Weakness-Opportunity)

a. Menambah jumlah tenaga pengangkut sampah.

b. Menambah jumlah sarana dan prasarana persampahan.

c. Meningkatkan kontribusi retribusi pelayanan persampahan/kebersihan dengan menambah atau memperluas cakupan pelayanan melalui peningkatan sosialisasi dan penyuluhan tentang persampahan.

d. Pengoptimalan pengawasan oleh DPRD dalam peningkatan kontribusi retribusi pelayanan persampahan/kebersihan.

3) Strategi ST (Strengh-Threats) 
a. Merevisi Perda Retribusi Pelayanan Persampahan/Kebersihan yang disesuaikan dengan perkembangan yang ada.

b. Penegakan sanksi bagi wajib retribusi.

c. Meningkatkan koordinasi dengan seluruh instansi terkait untuk mengatasi pesaing.

d. Meningkatkan pelayanan persampahan.

4) Strategi WT (Weakness-Threats)

a. Mengoptimalkan sosialisasi dan penyuluhan tentang Perda Retribusi Pelayanan Persampahan/Kebersihan termasuk mengenai tarif dan sanksi retribusi pelayanan persampahan/kebersihan.

b. Melakukan koordinasi dan kerjasama dengan pesaing yang ada untuk meningkatkan kontribusi retribusi pelayanan persampahan/kebersihan terhadap PAD.

c. Kaji ulang Perda Retribusi Pelayanan Persampahan/Kebersihan.

d. Revisi atau penyempurnaan SOP.

Grand strategy (strategi utama) dalam penelitian ini adalah strategi ekspansi dalam bentuk ekstensifikasi yaitu dengan melakukan perluasan cakupan layanan retribusi pelayanan persampahan/kebersihan di Kabupaten Situbondo, terutama untuk sektor permukiman dalam upaya untuk menambah target atas pendapatan retribusi pelayanan persampahan/kebersihan. Hal tersebut dikarenakan dengan melihat peluang yang begitu besar terkait dengan upaya peningkatan pendapatan atas retribusi pelayanan persampahan/kebersihan yaitu potensi permukiman terutama perumahan yang berkembang pesat dan masih banyak yang belum terjangkau, serta dengan melihat tingkat kesadaran masyarakat dalam membayar retribusi pelayanan persampahan/kebersihan juga baik. Selain itu, kontribusi dari retribusi pelayanan persampahan/kebersihan yang masih belum memberikan prosentase kontribusi pada Pendapatan Asli Daerah (PAD) Kabupaten Situbondo juga memberikan alasan perlunya peningkatan atau penambahan target retribusi pelayanan persampahan/kebersihan. Dalam perjalanannya, pelaksanaan penambahan target retribusi pelayanan persampahan/kebersihan sebagai strategi utama juga tetap harus diimbangi dengan pemberian pelayanan yang baik kepada masyarakat dan juga tetap diperlukan dukungan dari strategi-strategi lainnya.

\section{Kesimpulan}

Berdasarkan hasil analisis dan uraian yang telah dikemukakan sebelumnya, maka dapat diambil kesimpulan bahwa strategi utama yang dapat diterapkan Dinas PU Cipta Karya dan Tata Ruang Kabupaten Situbondo dalam upaya meningkatkan retribusi 
pelayanan persampahan/kebersihan pada permukiman adalah strategi ekspansi dalam bentuk ekstensifikasi yaitu dengan melakukan perluasan cakupan layanan retribusi pelayanan persampahan/kebersihan di Kabupaten Situbondo terutama untuk sektor permukiman. Dimana, untuk keberhasilan strategi utama tersebut diperlukan dukungan dari strategi-strategi yang lain.

\section{Saran}

Berdasarkan hasil analisis dan uraian yang telah dikemukakan sebelumnya, maka saran yang dapat diberikan adalah sebagai berikut:

a. Bagi Pemerintah Kabupaten Situbondo khususnya Dinas PU Cipta Karya dan Tata Ruang Kabupaten Situbondo

1) Dinas PU Cipta Karya dan Tata Ruang dapat menggunakan matriks IE dan matriks SWOT untuk merumuskan beberapa alternatif strategi yang dapat digunakan untuk meningkatkan pendapatan atas retribusi pelayanan persampahan/kebersihan.

2) Dinas PU Cipta Karya dan Tata Ruang sebagai leading sector atas retribusi pelayanan persampahan/kebersihan harus berupaya untuk bisa menerapkan sistem manajemen retribusi daerah yang baik, yaitu:

a) rutin melakukan pendataan potensi/update potensi wajib retribusi pelayanan persampahan/kebersihan untuk menjaring potensi-potensi baru yang belum tergali,

b) rutin melakukan pengkajian dan pengevaluasian atas tarif retribusi pelayanan persampahan/kebersihan maksimal 3 (tiga) tahun sekali,

c) rutin melakukan penilaian kembali atas wajib retribusi yang disesuaikan dengan perkembangan ekonomi dan atau volume timbulan sampah yang dihasilkan,

d) memperbaiki sistem pengawasan terutama oleh instansi pemerintahan yang terkait dalam upaya untuk mengatasi atau mengurangi kebocoran atas retribusi pelayanan persampahan/kebersihan,

e) menegakkan sanksi bagi petugas pemungut yang melakukan pelanggaran dan pemberian reward bagi petugas yang disiplin dan melakukan tugasnya dengan baik,

f) menjalin kerjasama dengan berbagai pihak dalam upaya untuk meningkatkan pendapatan atas retribusi pelayanan persampahan/ kebersihan maupun dalam memberikan kemudahan dan kenyamanan dalam membayar retribusi sampah. 
3) Dinas PU Cipta Karya dan Tata Ruang selalu memberikan pelayanan persampahan yang baik kepada masyarakat, baik pelayanan dalam pengelolaan sampah (kebersihan sampah) maupun pelayanan atas retribusi pelayanan persampahan/kebersihan.

4) Dinas PU Cipta Karya dan Tata Ruang juga harus secara rutin melakukan sosialisasi persampahan, terutama terkait retribusi pelayanan persampahan/kebersihan kepada masyarakat.

5) Dinas PU Cipta Karya dan Tata Ruang secara rutin melakukan perbaikan dan revisi atau penyempurnaan atas Standar Operasional Prosedur (SOP) retribusi pelayanan persampahan/kebersihan, karena tanpa revisi/penyempurnaan, SOP tidak akan mampu mengimbangi dinamika usaha yang telah dilakukan.

b. Bagi akademisi atau peneliti lain

Penelitian dapat dilakukan dengan tema dan fokus penelitian yang sama, dengan lebih banyak menggali informasi yang bersumber dari luar instansi yang terkait langsung ataupun dari luar pemerintahan (masyarakat), sehingga dapat menambah faktor-faktor eksternal terkait strategi peningkatan retribusi pelayanan persampahan/kebersihan pada permukiman di Kabupaten Situbondo.

\section{Daftar Referensi}

Amirullah. 2015. Manajemen Strategi Teori-Konsep-Kinerja. Jakarta : Mitra Wacana Media

David, Fred R. 2009. Strategic Management. Twelfth Edition. New Jersey: Pearson Education. Terjemahan oleh Dono Sunardi. 2011. Strategic Management (Manajemen Strategi Konsep), Buku 1, Edisi 12. Jakarta: Salemba Empat

Djalil, Rizal. 2014. Akuntabilitas Keuangan Daerah (Implementasi Pasca Reformasi). Jakarta: PT.Wahana Semesta Intermedia

Halim, Abdul. 2004. Bunga Rampai Manajemen Keuangan Daerah Edisi Revisi. Yogyakarta:UPP AMP YKPN

Peraturan Daerah Situbondo Nomor 5 Tahun 2011. Retribusi Pelayanan Persampahan/Kebersihan. 7 April 2011. Lembaran Daerah Kabupaten Situbondo Tahun 2011 Nomor 5. Situbondo

Rozzaq, Gozzali AR . 2010. Kontribusi dan Efektifitas Retribusi Jasa Umum terhadap Penerimaan Pendapatan Asli Daerah Kota Surakarta Tahun 2005-2009. Skripsi. Surakarta: Universitas Sebelas Maret

Sofyan, Iban. 2015. Manajemen Strategi (Teknik Penyususnan serta Penerapannya untuk Pemerintah dan Usaha). Yogyakarta: Graha IImu 